\title{
Geophagic clay around Uteh-Uzalla near Benin: mineral and trace elements compositions and possible health implications
}

\author{
lyobosa Timothy Asowata ${ }^{1}$ \\ Received: 30 November 2020 / Accepted: 8 April 2021 \\ Published online: 20 April 2021 \\ (c) The Author(s) $2021 \quad$ OPEN
}

\begin{abstract}
Geophagic clay consumption, which is an age-long cultural practice by humans and animals in many parts of the world, and particularly in Nigeria, may have long time health effects on the consumers. This is particularly so because of the relatively high concentration of harmful minerals and toxic elements. This study sought to determine the mineralogical and trace element compositions of geophagic clay in Uteh-Uzalla area, which is underlain by the Benin Formation of Oligocene to Miocene age, in order to evaluate the potential health risk associated with the consumption of the clay. Sixteen clay samples were collected from mine face profiles of an open pit, analysed for mineral and trace element compositions, using $\mathrm{x}$-ray diffraction technique and ultra-trace inductively coupled plasma mass spectrometry (ICPMS) methods, respectively. The mean mineral concentration in \% includes kaolinite, quartz and smectite $(64.88,19.98$, and 9.54), respectively, among other minerals. And the mean concentrations in $\mathrm{mg} / \mathrm{kg}$ for $\mathrm{Cu}$ (15.0), $\mathrm{Pb}$ (14.4), $\mathrm{Zn}$ (30.9), Co (8.9), Mn (39.4) and Th (10.5) among other elements were found in the clay. From the trace elements results when compared with health risk indices by Agency for Toxic Substances and Diseases Registry (ATSDR): Minimum Risk Level, recommended daily intake and estimated daily intake, it was found that the elements are far above the daily oral intake requirement. Also, considering the relatively low $\mathrm{pH}$ (acidic) values that were exhibited by the clays, harmful minerals and elements contained in the clay may be bioavailable in the internal system among those who are frequently involved in the consumption of the clay.
\end{abstract}

Keyword ICP-MS · Quartz · Clay profile · Health risk · X-ray diffraction

\section{Introduction}

The act of consumption of earth or soil-like materials such as clay is referred to as Geophagia or Geophagy, and such clay is referred to as geophagic clay. It occurs in animals where it may be a normal or abnormal behaviour, and also in humans, most often in rural or preindustrial societies among children and pregnant women [1, 2]. Sometimes the practice can also be seen among urban residences, as seen in the sale of the produced clay in many urban markets in Nigeria, [1-5]. Geophagic clay consumption has been reported to be age long, since four hundred (400) years back, and the act had been practiced by different cultures, $[2,6-8]$. Human geophagia may be related to pica, a psychological disorder characterized by an appetite for substances that are largely nonnutritive, such as ice (pagophagia); hair (trichophagia); paper (xylophagia); stones (lithophagia) or soil (geophagia); and chalk. [9,

Supplementary Information The online version contains supplementary material available at https://doi.org/10.1007/s42452-021-04565w.

lyobosa Timothy Asowata, itasowata@futa.edu.ng; timoti4x@yahoo.co.uk|'Department of Applied Geology, School of Earth and Mineral Sciences, Federal University of Technology, Akure, Nigeria. 
10], pointed out that geophagic constituents could act as a lubricant for fibrous forages, provide extra minerals and stimulate the flow of saliva, which contain high concentration of sodium $(\mathrm{Na})$ and phosphorus $(\mathrm{P})$ and could thus relieve a mineral shortage in the rumen, which is also supported by [11]. Historically, and today in Nigeria, geophagia is almost synonymous with clay consumption and some pregnant women patronise those who sell the commodity, $[1,5]$. Areas in Africa where such practices are in existence include; South Africa, Nigeria, Cameron, Uganda, Tanzania, Ghana, [9, 11-13], among many other areas of the continent.

Many research works have been carried out on the evaluation of essential elements in geophagic clay for effective curative of both skin and intestinal disorder among pregnant women, and recommended pharmaceutical regulatory agency to effectively put control on its consumption, $[1,14-16]$. The metal and mineralogical characteristics of clay in many parts of Nigeria such as Ibadan, Benin, Calabar and other Southern parts of Nigeria, $[2,4,5,9]$ as well as some of the other parts of Africa have been carried out with a view to finding the total metal content and possible health implications on their consumer [17-19]. Result showed that for the Calabar clay, it was relatively enriched with $\mathrm{Zn}, \mathrm{Pb}$ and other potentially harmful elements, using inductively coupled plasma mass spectroscopy (ICP-MS) and the findings showed that these elements may probably be the cause of high prevalence of hypertension, cardiac failures and gastrointestinal problems within the study areas, [5]. Similar results have been observed and recommendations were given for communities in Free State province of South Africa, [20]. The works of [21-25], have reported the possible presence of high concentration of potentially harmful elements such as $\mathrm{Pb}, \mathrm{Cu}, \mathrm{As}$, $\mathrm{Zn}$ and $\mathrm{Hg}$ and radionuclides such as $\mathrm{Th}, \mathrm{La}$ and $\mathrm{U}$ in the clays and emphasized the need for more qualitative scientific investigation to avoid possible consumption of toxic elements. Recently, [16] carried out in detail the mineralogical, geochemical and health impacts of that earth materials consumed by humans in Vhembe district in Limpopo province, South Africa and found out that there are essential elements like selenium in them that could be extracted for immune booster for HIV patents, [16]. It was therefore recommended that pregnant women and children that consume this clay material without control should seek protection against gastrointestinal problem and toxin because of the possible high bioaccessibility of some potentially harmful elements like $\mathrm{Hg}, \mathrm{As}, \mathrm{Pb}$ and $\mathrm{Zn}$ found to be high in both in their intestine and stomach, [16]. The works of $[22,26-29]$ further reported the relevance of carrying out bioaccessibility and bioavailability of geophagic clay in the human internal system in order to know the relative health risk that such clay consumption poses to the human beings. Issues relating to frequency of consumption, which brings about gradual build-up over time of these elements in the vital organs of the body, the nature of the chemical species and oxidation state of these harmful elements, soil $\mathrm{pH}$, stomach and intestinal $\mathrm{pH}$, soil-to-solution ratio and fasting condition can increase health risk. The causes and consequences of geophagic clay consumption were studied by [30], using in vivo type of bioaccessibility, to check for Fe content enrichment in the hemoglobin, duodenal cytochrome and ferroportin of the internal system. And it was analysed, using Inductively Coupled Plasma Atomic Emission Spectroscopy (ICPAES). It was observed that there were low (minimal) impacts of $\mathrm{Fe}$ in those parts of the internal systems studied. These findings were also in agreement with the in vitro study that was carried out with smectite of Ugandan geophagic clay using Caco-2 model by [31]. This finding showed that in consuming the clay, there was no significant increase of bioavailability of Fe in the internal system; hence, there was no significant health effect of the consumption of the clay [31]. Similarly, the bioavailability studies of trace elements such as lead $(\mathrm{Pb})$, cadmium $(\mathrm{Cd})$ and mercury $(\mathrm{Hg})$ were carried out by [32]. The study showed that bioaccessibility of $\mathrm{Pb}$ intake by person (pregnant women) weighing $60 \mathrm{~kg}$ exceeds the provisional tolerable daily intake (PTDI) of $0.0036 \mathrm{mg} / \mathrm{kg}$ body weight when more than $10 \mathrm{~g}$ of the clay are consumed per day as well as when bioavailability of $\mathrm{Pb}$ is relatively high, say $>10 \%$. The study also showed that newborn babies ( $3 \mathrm{~kg}$ body weight) are at higher risk of exceeding the provisional tolerable daily intake of $\mathrm{Pb}$. Low quantity of $\mathrm{Hg}$ and $\mathrm{Cd}$ was also recorded in the internal system, suggesting that the daily ingestion of geophagic clay does not contribute to unsafe mercury and Cadmium intake for both adult and newborn babies for that particular study. Exposure of lead to pregnant and breast-feeding women is of higher risk, as reported by [33, 34]. This is because it was observed that the metal easily crosses the placenta and migrate (absorbed) into breast milk even at a relatively low exposure, causing adverse effects on child's neurodevelopment and physical growth. Similarly, [11] studied some major elements as well as toxic metal concentrations in clay in Volta region of Ghana, using Inductively Coupled Plasma Mass Spectrometry (ICP$\mathrm{MS})$. The elements were iron (Fe), copper $(\mathrm{Cu})$, zinc $(\mathrm{Zn})$, potassium (K), magnesium (Mg), sodium $(\mathrm{Na})$, arsenic $(\mathrm{As})$, manganese $(\mathrm{Mn})$, lead $(\mathrm{Pb})$ and nickel $(\mathrm{Ni})$. This clay was found to be consumed by pregnant women in the study area. The results showed that $\mathrm{Fe}, \mathrm{Cu}, \mathrm{Zn}, \mathrm{K}, \mathrm{Mg}, \mathrm{Na}, \mathrm{As}, \mathrm{Mn}$, $\mathrm{Pb}$, and $\mathrm{Ni}$, recorded 1.38, 2.40, 7.74, 4.01, 13.24, 13.76, $1.63,4.72,0.53$ and 1.85 , respectively, in $\mu \mathrm{g} / \mathrm{kg}$. Harmful elements such as $\mathrm{As}, \mathrm{Mn}, \mathrm{Pb}$ and Ni were further compared with World Health Organization [35] threshold recommendation at $\mu \mathrm{g} / \mathrm{kg}$ at $60 \mathrm{~kg}$ body weight per day of 3.0, 4.9, 3.0 
and 5.0, respectively. From the result, [Kortei el al., 2020] opined that the cumulative effect of the consumption of the clay may cause detrimental effect on the foetus of the unborn child. Hence the need for proper evaluation in other to know the places wher thes clays are mined and sold. In Nigeria, most works that have been carried out, which have only been done by first sampling from the market places where most of the clays are sold $[2,4,22]$ as well as determination of total metal content in the evaluated clay. Till date, no known published work has been carried out on the total metal content, mineral composition determination in the deposits where these clays are mined, processed and sold for consumption in this study area. Hence, the aim of this research is to evaluate the mineral composition and trace elements concentration in the geophagic clay in the study area (at Uteh-Uzalla, near Benin City) (Fig. 1) in order to check the possible health risk if any, in the consumption of the geophagic clay.

\section{Geology of the area}

The study area falls within the Benin Formation, which is of Oligocene to Miocene age, in Fig. 2, which is the youngest in the sequence of formations in the Niger Delta Basin, [36]. The other two formations are Akata and Agbada, [36-38]. The lithologies of the Benin Formation comprise of reddish brown sands, silt, sandstone and clay, which are generally referred to as coastal plain sand, $[39,40]$. In some localized areas, the clay thickness, as presented in Fig. 1 of the supplementary Material, is significantly above $30 \mathrm{~m}$, while in some other areas, they appears as thin beds of less than one (1) meter. Their colours also vary from light brown, reddish brown and pale white colours as observed in the field study. The mined clay samples are cut to sizes as seen in Fig. 2 of supplementary material, and loaded in sack bags for firing before sale, in Fig. 3 of supplementary material.

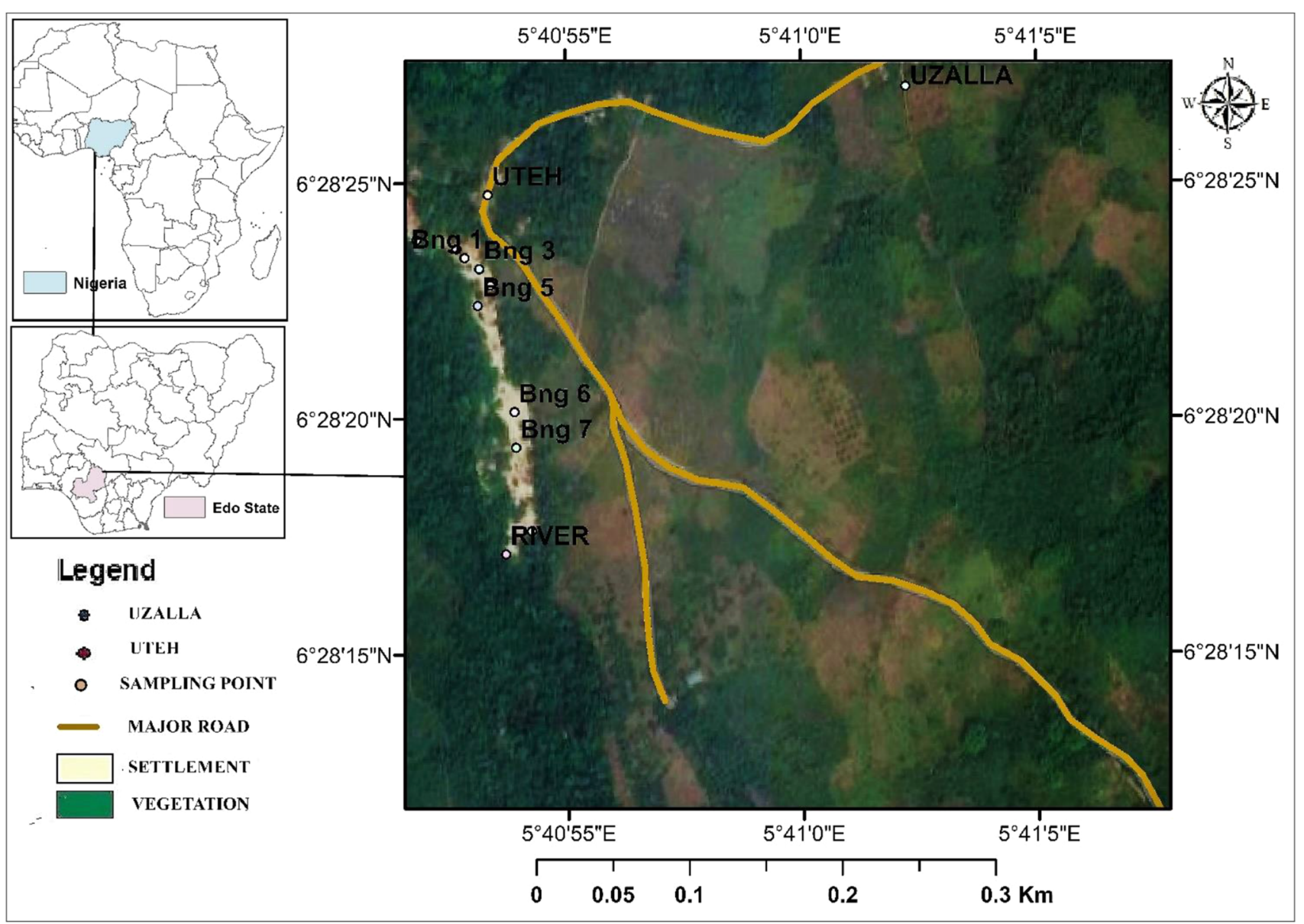

Fig. 1 Study location map 


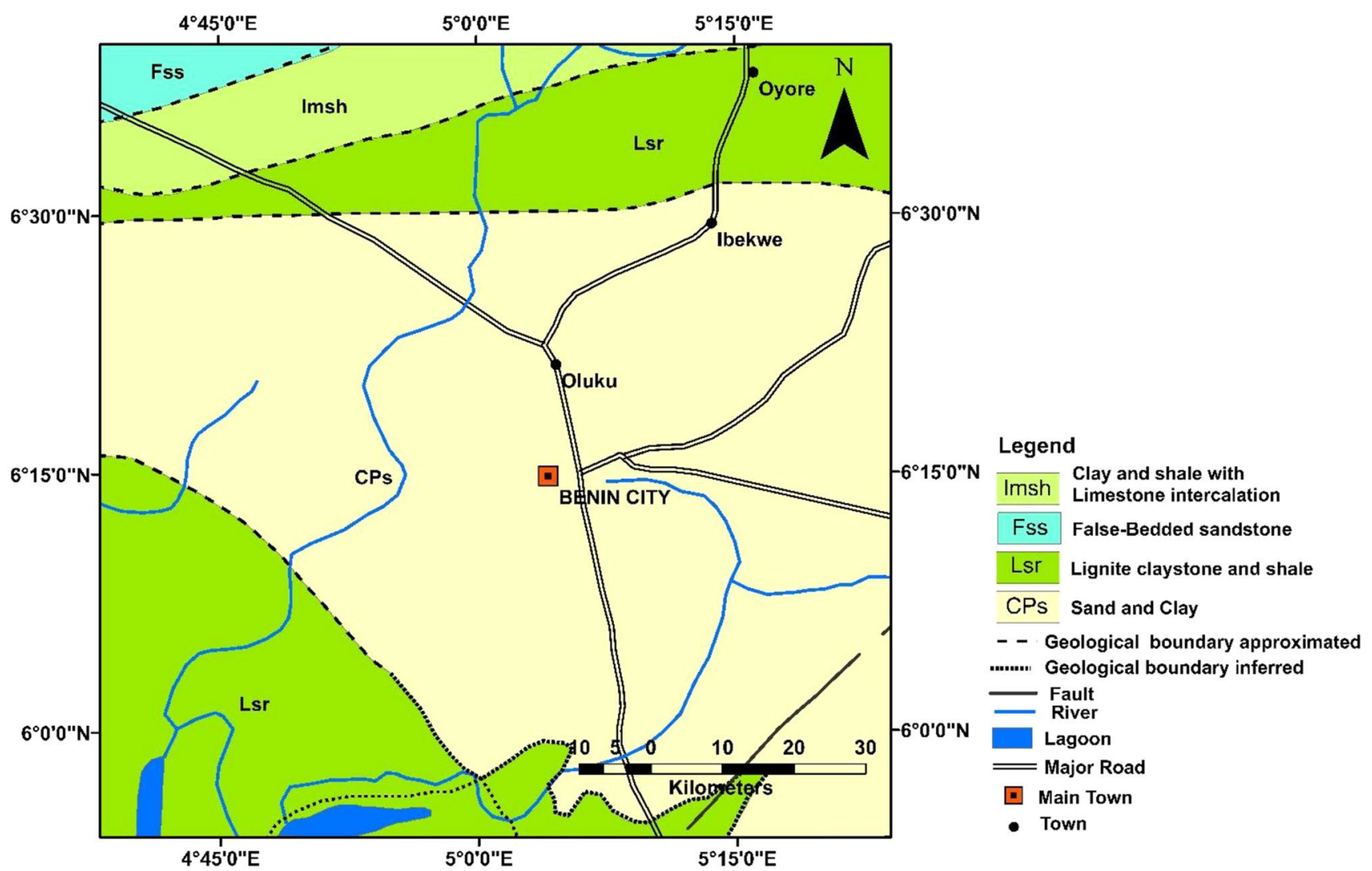

Fig. 2 Geologic Map of Benin area [4]

\section{Materials and methods}

The clay sample at the study area which is an open pit mining site was identified from the various open pits in the mining site. These open pits were made so because of the ways artisanal miners carry out the mining activities and sixteen (16) clay samples were collected. It was observed at the mining site that the clays were separated by the miners between the consumed type and the one that are not consumed (Fig. 1 of the supplementary material). The variation betwen the one collected for consumption was observed from their lotho-strata in the mining site. The top layer of the clay sequence were not mined for consumption, hence, the top layer are discarded at the mine site by the miners, while the bottom layer were collected for consumption. This variation was easily identified in the exposed strata based on their colour and grain size variation within the litho-sequence based on field study. The clay samples that were collected were air dried at room temperature of $26^{\circ} \mathrm{C}$ based on the average temperature in Akure, Nigeria and after three (3) days, the samples were pulverized and stored in polythene bags for physicochemical, geochemical and mineralogical analyses. For the physicochemical analyses, $120 \mathrm{ml}$ of deionized water were added to $20 \mathrm{~g}$ of clay samples in a beaker, and were allowed to stay for $48 \mathrm{~h}$ at room temperature of $26^{\circ} \mathrm{C}$. Thereafter, $\mathrm{pH}$, electrical conductivity (EC) and total dissolved solid (TDS) were measured using multi-pH meter, at the Geochemistry laboratory of Marine Department, Federal University of Technology, Akure. Similarly, the trace elements concentration of the clay samples was determined, using $0.5 \mathrm{~g}$ of sieved clay samples at $>53 \mu \mathrm{m}$ mesh fraction from the pulverized (Pulp) samples. Before the geochemical analysis, the clay samples were digested using aqua regia. The process involves gradual adding of $5 \mathrm{ml}$ of nitric acid (Merck Suprapur of $65 \%$ ), then, addition of $2 \mathrm{ml}$ of hydrochloric acid (Merck Suprapur 36\%), and $10 \mathrm{ml}$ of ultrapure water (18 m' $\Omega-\mathrm{cm}$ of specific resistivity) in a clean Pyrex tube. The samples were heated at a temperature of $95^{\circ} \mathrm{C}$ for a period of $2 \mathrm{~h}$ in a microwave oven. Later the samples were poured into a $50-\mathrm{ml}$ volumetric flask, and the solution filtered, extracted by a disposable syringe and made to be filtered with a 0.45 filter membrane before the analysis was carried out, and subsequently analysed using ultra-trace inductively coupled plasma mass spectrometry method (ICP-MS) (AVIO 200, PerkinElmer, MA, USA). The quality assurance and quality control procedure were carried out; blank samples testing along with the samples analysed were carried out in group, together with reference certified materials according

\section{SN Applied Sciences}


to ACME laboratory protocol. Also, duplicate samples were analysed simultaneously for $20 \%$ of the total clay samples and the standard deviations of the samples were averagely found to be under $10 \%$ from the expected values. The minimum detection limits of the analysed trace in $\mathrm{mg} / \mathrm{kg}$ were $\mathrm{Cu}$ (1.0), Pb (3.0), Zn (1.0), Co (1.0), Mn (2.0), Th (2.0), Sr (1.0), $\mathrm{V}$ (1.0), $\mathrm{La}(1.0), \mathrm{Cr}(1.0), \mathrm{Ba}(1.0), \mathrm{Sc}(5.0)$ and $\mathrm{Ni}$ (1.0). The sensitivity of the equipment in terms of the minimum detection limit (MDL) as declared by the laboratory was satisfactory for the determined elements. X-ray diffraction (XRD) technique analysis was also carried out for eight (8) at of the sixteen (16) samples, using $45 \mathrm{~g}$ of the clay samples. These include the consumed and the nonconsumed clay samples at the XRD Analytical and Consulting CC, Lynnwood Glenn, South Africa. The clay samples were prepared for XRD analysis using a back loading preparation method. It was analysed with a Malvern Panalytical Aeris diffractometer with PIXcel detector and fixed slits with Fe filtered Co-K a radiation. The phases were identified using X'Pert High score plus software. The relative phase amounts (weights \%) were estimated using the Rietveld method.

Similarly, estimation of geophagic clay intake was carried out. The mean daily intake (MDI) of the consumed clay analysed was estimated to be $20 \mathrm{~g}$. This estimation was arrived at as a relatively conservative outcome from published works in some countries in Africa and in Nigeria particularly, $[2,4,5,9,41,42]$. This estimate became appropriate based on anecdotal evidences about consumption pertain in their studies. The probable daily intake (PDI) of the selected elements was calculated by multiplying the mean concentration of the trace elements $(T)$ by the mean daily consumption, under an assumed body weight of $60 \mathrm{~kg}$, which is a major parameter in human health metabolisms [41].

$\mathrm{PDI}=[T \times \mathrm{MDC}]$

where $\mathrm{MDC}=$ mean daily consumption $(\mu \mathrm{g})$.

The results were compared against recommended mean daily intake by the Joint WHO/FAO Committee on Food Additives (JECFA) [35].

\section{Results and interpretation}

\subsection{Physicochemical characteristics}

The result of the $\mathrm{pH}$ in both the consumed and nonconsumed clays in the study area showed that it ranged from 3.19 as seen in sample Bng4 to 6.01 as observed in Bng2A. The $\mathrm{pH}$ of clay samples showed that they are generally slightly to moderately acidic (Table 1). However, the result for the electrical conductivity (EC) ranges in $\mu \mathrm{S} / \mathrm{cm}$ from 11.0 to 1861 , indicating a wide range of variation of EC in the clay sample. Similar variation result in the Total Dissolved Solid (TDS) was observed in the clay samples. The TDS values showed that it ranges in $\mathrm{mg} / \mathrm{l}$ from 5.0 to 935 . It was generally observed that there were no clear variations in the physicochemical parameters measured between the consumed clay samples from the nonconsumed clay samples.

Trace elements concentration in the geophagic clay samples (Table 2 ) showed that $\mathrm{Cu}(\mathrm{mg} / \mathrm{kg}$ ) ranges from Below Detection Limit (BDL) $(<1)-21.0$, mean 15.0, standard deviation \pm 7.09$)$. $\mathrm{Pb}(13.0-18.0$; mean $14.4 ; \pm 1.86)$ $\mathrm{mg} / \mathrm{kg}$, Zn (4.0 -76.0, mean $30.9 \pm 27.25) \mathrm{mg} / \mathrm{kg}$, Co $(1.0$ - 16.0; mean 8.9; standard deviation \pm 5.22$) \mathrm{mg} / \mathrm{kg}, \mathrm{Mn}$ (8.0 - 128.0; mean 39.4, \pm 37.80$) \mathrm{mg} / \mathrm{kg}$ and Th $(6.0-14.0$; mean 10.5 standard deviation \pm 2.27$) \mathrm{mg} / \mathrm{kg}$ among other trace elements determined. It was observed that there were relative variations in elemental concentration in both the consumed and nonconsumed clay samples analysed from one sample pit to the other.

The highest concentrations of $\mathrm{Cu}$ for the consumed clay were at pit $\mathrm{BnG} 6 \mathrm{~A}$ and $\mathrm{BnG} 8 \mathrm{~A}$ with a concentration of $21.00 \mathrm{mg} / \mathrm{kg}$, respectively, while pit BnG1A was below detection limit, as the only sample was $\mathrm{Cu}$ was not detected. $\mathrm{Pb}$ was found in all the samples analysed, with the highest concentration of $\mathrm{Pb}, 18.0 \mathrm{mg} / \mathrm{kg}$ in $\mathrm{BnG} 3 \mathrm{~A}$, while the lowest concentrations of $13.0 \mathrm{mg} / \mathrm{kg}$ were found in samples $B n G 1 B, B n G 5 A, B n G 7 A$ and $B n G 9$, respectively. Similarly, $\mathrm{Zn}$ was recorded in all the samples analysed. The
Table 1 Physicochemical properties of the clay in the study area

\begin{tabular}{|c|c|c|c|c|c|c|c|}
\hline & \multicolumn{2}{|c|}{ Consumed Clay } & \multirow[b]{2}{*}{ TDS (mg/l) } & & \multicolumn{3}{|c|}{ Nonconsumed Clay } \\
\hline & $\overline{\mathrm{pH}}$ & $\mathrm{EC}(\mu \mathrm{s} / \mathrm{cm})$ & & & $\overline{\mathrm{pH}}$ & $\mathrm{EC}(\mu \mathrm{s} / \mathrm{cm})$ & TDS (mg/l) \\
\hline $\mathrm{BnG} 1 \mathrm{~A}$ & 3.74 & 33 & 17 & BnG1B & 4.51 & 13 & 6 \\
\hline $\mathrm{BnG} 2 \mathrm{~A}$ & 3.46 & 400 & 199 & $B n G 2 B$ & 6.01 & 11 & 5 \\
\hline $\mathrm{BnG} 3 \mathrm{~A}$ & 3.12 & 1861 & 935 & BnG3B & 4.05 & 25 & 12 \\
\hline $\mathrm{BnG5A}$ & 3.23 & 745 & 374 & BnG4 & 3.19 & 1061 & 531 \\
\hline $\mathrm{BnG6A}$ & 3.37 & 405 & 203 & Bng5B & 5.62 & 13 & 7 \\
\hline BnG7A & 6.02 & 13 & 6 & BnG6B & 4.86 & 22 & 11 \\
\hline $\mathrm{BnG} 8 \mathrm{~A}$ & 3.55 & 322 & 161 & BnG7B & 3.31 & 1479 & 740 \\
\hline BnG9 & 3.86 & 33 & 17 & BnG8B & 3.28 & 1193 & 598 \\
\hline
\end{tabular}


Table 2 Trace elements compositions of the geophagic clay in the study area in $\mathrm{mg} / \mathrm{kg}$

\begin{tabular}{|c|c|c|c|c|c|c|c|c|}
\hline \multirow[t]{2}{*}{ Element } & \multirow[t]{2}{*}{ Min } & \multicolumn{4}{|c|}{ Consumed Clay $(n=8)$} & \multicolumn{3}{|c|}{ Nonconsumed Clay $(n=8)$} \\
\hline & & Max & Mean & Std. Dev & Min & Max & Mean & Std. Dev \\
\hline $\mathrm{Cu}$ & $\mathrm{BDL}$ & 21.0 & 15.0 & 7.09 & 3.0 & 26.0 & 12.75 & 8.35 \\
\hline $\mathrm{Pb}$ & 13.0 & 18.0 & 14.4 & 1.85 & 10.0 & 17.0 & 14.25 & 2.05 \\
\hline $\mathrm{Zn}$ & 4.0 & 76.0 & 30.9 & 27.25 & 3.0 & 56.0 & 12.00 & 18.29 \\
\hline Co & 1.0 & 16.0 & 8.9 & 5.22 & 1.0 & 7.0 & 2.00 & 2.14 \\
\hline $\mathrm{Mn}$ & 8.0 & 128.0 & 39.4 & 37.80 & 3.0 & 22.0 & 9.50 & 7.35 \\
\hline Th & 6.0 & 14.0 & 10.5 & 2.27 & 9.0 & 14.0 & 11.13 & 1.73 \\
\hline $\mathrm{Sr}$ & 10.0 & 19.0 & 13.5 & 2.93 & 5.0 & 17.0 & 12.13 & 4.02 \\
\hline V & 23.0 & 35.0 & 27.8 & 4.59 & 25.0 & 64.0 & 38.88 & 14.42 \\
\hline La & 10.0 & 33.0 & 16.1 & 7.45 & 14.0 & 26.0 & 21.38 & 4.90 \\
\hline $\mathrm{Cr}$ & 17.0 & 29.0 & 24.3 & 3.65 & 19.0 & 38.0 & 25.38 & 6.14 \\
\hline $\mathrm{Ba}$ & 34.0 & 104.0 & 60.0 & 22.49 & 14.0 & 98.0 & 43.38 & 29.75 \\
\hline Sc & 5.0 & 9.0 & 7.3 & 1.28 & 5.0 & 10.0 & 7.38 & 1.69 \\
\hline $\mathrm{Ni}$ & 0.5 & 22.0 & 14.6 & 7.69 & 0.5 & 15.0 & 3.44 & 5.12 \\
\hline
\end{tabular}

highest concentration of $\mathrm{Zn}$, was found in $\mathrm{BnG} 2 \mathrm{~B}, 76 \mathrm{mg} /$ $\mathrm{kg}$, sample $B \mathrm{nG} 5 \mathrm{~A} 64 \mathrm{mg} / \mathrm{kg}$ also recorded relatively higher enrichment of $\mathrm{Zn}$. However, BnG1B $4.0 \mathrm{mg} / \mathrm{kg}$, showed the lowest concentration of $\mathrm{Zn}$. Similar variation in concentration was exhibited by the selected trace elements in both the consumed and unconsumed geophagic clays. Comparatively, the mean concentrations in $\mathrm{mg} / \mathrm{kg}$ of $\mathrm{Cu}$, (12.75), $\mathrm{Pb},(14.25), \mathrm{Zn}$, (30.9) Co, (8.9), among other trace elements were found to be higher in the nonconsumed clay, Cu, (12.75), Pb, (14.25), Zn, (12.00), Co, (2.0) and Mn (9.50) except for V, (27.8), La (16.1) and Cr (24.3) that the mean concentration for the consumed clay is lower than the nonconsumed clay, $\mathrm{V}$ (38.88), La (21.88) and $\mathrm{Cr}$ (23.38), respectively.

The average elemental concentrations of the selected trace elements in the geophagic clay were compared with some published article's reports published elsewhere. It was observed that the mean concentration of these selected trace elements in the geophagic clay of this study is relatively lower than many of the clay consumed elsewhere and sometime higher, but generally of close similarity in elemental concentrations. For example, the mean concentration in $\mathrm{mg} / \mathrm{kg}$ for $\mathrm{Cu}(15.0)$ in this study is lower than clay studied in Kano (16.1), Asaba (19.88) and Cameroon (42.0), but higher than the clay samples analysed in Katsina (7.6), Calabar (14.3) and Okon-Eket (12.17). The mean concentration for $\mathrm{Pb}$ (14.4) is found to be higher than the $\mathrm{Pb}$ mean concentration for Kano (11.5) and Katsina (6.3) but lower than the mean concentration for Asaba (46.3), Calabar (36.48), Okon-Eket (33.8) and Cameroon (24.0). Similar trend was observed in $\mathrm{Zn}, \mathrm{Co}$ among other trace elements (Table 3).

Also, the mean concentrations for $\mathrm{Cu}, \mathrm{Pb}, \mathrm{Zn}, \mathrm{Co}, \mathrm{Mn}$, Th, $\mathrm{Sr}, \mathrm{V}, \mathrm{La}, \mathrm{Cr}, \mathrm{Ba}, \mathrm{Sc}$, and $\mathrm{Ni}$ were observed to be lower than the mean result of these same elements in the average shale concentration (ASC) according to [43] (Table 3). This suggests that the consumed clay sample have lower enrichment of these selected trace elements concentration than the average shale concentration. The mean concentration in $\mathrm{mg} / \mathrm{kg}$ for $\mathrm{Cu}, \mathrm{Pb}, \mathrm{Zn}, \mathrm{Co}, \mathrm{Mn}, \mathrm{Th}, \mathrm{Sr}, \mathrm{V}$, $\mathrm{La}, \mathrm{Cr}, \mathrm{Ba}, \mathrm{Sc}$, and Ni were also compared with the average Continental Crust Composition by [44] (Table 3). From the result, it was observed that the mean concentration of these elements in this study were lower than the average Continental Crust concentration except $\mathrm{Pb}$ (5.0), Th (2.0) and $\mathrm{La}$ (11) when compare to $\mathrm{Pb}$, Th and La of this study with mean concentration of 14.4 and $14.25,10.5$ and 11.13 , 16.1 and 21.38, respectively, for both consumed clay and the nonconsumed clay (Table 3). This may have been influenced by the grain size of the clay samples in this study, which may have increased the absorption surface.

Similarly comparison was carried out between the trace elements of this study with the minimum risk level recommended by Agency for Toxic Substances and Diseases Registry (ATSDR), [45] and recommended daily intake of trace elements in the human system [46]. It was revealed that these elements exceeded the minimum risk level as prescribed as well as the expected amount in the body system (Table 3). This was also observed in Table 4, where by the estimated probable daily intake (PDI) was higher that the WHO/FAO, 2011 recommended daily intake in all the available elements that were compared with WHO/FAO daily intake standards as seen in $\mathrm{Cu}$ (threefold higher), $\mathrm{Pb}$ ( 6 folds higher), among other elements. This suggests that the continuous consumption of this clay may pose significant health risk, especially with the continues accumulation of these harmful elements over a long period of time as revealed by [32].

The presence of elements such as $\mathrm{Pb}, \mathrm{Th}, \mathrm{La}$ and $\mathrm{Sc}$ in the analysed samples may pose some health risk to those 
Table 3 Comparison of mean concentration of trace elements in clays the study area with other published works in $\mathrm{mg} / \mathrm{kg}$

\begin{tabular}{lllllllllllllll}
\hline Ele & Mean $^{\mathrm{a}}$ & Mean $^{\mathrm{b}}$ & $\mathrm{A}$ & $\mathrm{B}$ & $\mathrm{C}$ & $\mathrm{D}$ & $\mathrm{E}$ & $\mathrm{F}$ & $\mathrm{G}$ & $\mathrm{H}$ & $\mathrm{I}$ & $\begin{array}{l}\text { ATSDR } \\
\text { (mg/kg/ } \\
\text { day) }\end{array}$ & $\begin{array}{l}\text { Recommended } \\
\text { Daily intake mg/ } \\
\mathrm{kg} / \mathrm{day}\end{array}$ \\
\hline $\mathrm{Cu}$ & 15.0 & 12.75 & 16.1 & 7.6 & 19.88 & 14.13 & 12.17 & 42 & 32.25 & 50 & 90 & 0.01 & $1.0-1.5$ \\
$\mathrm{~Pb}$ & 14.4 & 14.25 & 11.5 & 6.3 & 46.3 & 36.48 & 33.8 & 24 & 1.53 & 20 & 5.0 & NST & NST \\
$\mathrm{Zn}$ & 30.9 & 12.00 & 15.5 & 3.0 & 40.4 & 46.0 & 41.29 & 110 & 32.63 & 90 & 83 & 0.3 & $10-15$ \\
$\mathrm{Co}$ & 8.9 & 2.00 & 5.25 & 2.8 & 13.56 & 6.78 & 5.77 & 1.5 & 29.0 & 20 & 33 & 0.0001 & $0.002-0.1$ \\
$\mathrm{Mn}$ & 39.4 & 9.50 & - & - & & 76.83 & 106.43 & - & - & 850 & - & 0.3 & $2-3$ \\
$\mathrm{Th}$ & 10.5 & 11.13 & 18.6 & 16.3 & 13.9 & - & - & 24 & 8.1 & 12 & 2.0 & NST & NST \\
$\mathrm{Sr}$ & 13.5 & 12.13 & 96.8 & 121.4 & 80.13 & - & - & 64 & 73.9 & 400 & 220 & 2.0 & $0.5-1.5$ \\
$\mathrm{~V}$ & 27.8 & 38.88 & - & - & - & - & - & 84 & 124.0 & 130 & 271 & 0.01 & - \\
$\mathrm{La}$ & 16.1 & 21.38 & - & - & - & - & - & - & 99.85 & 40 & 11 & NST & NST \\
$\mathrm{Cr}$ & 24.3 & 25.38 & - & - & - & - & - & 1.5 & 124.24 & 100 & 219 & 0.0001 & NA \\
$\mathrm{Ba}$ & 60.0 & 43.38 & - & - & - & - & - & 330 & - & - & 150 & 0.2 & NA \\
$\mathrm{Sc}$ & 7.3 & 7.38 & - & - & - & - & - & 18 & - & - & 35 & NST & NA \\
$\mathrm{Ni}$ & 14.6 & 3.44 & 6 & 1.7 & - & 23.87 & 22.6 & 42 & 30.7 & 80 & 156 & 0.0002 & $2-3$ \\
\hline
\end{tabular}

NST $=$ No safe Threshold

$\mathrm{NA}=$ Not Available

A-Kanu-[2]

B-Kastina-[4]

C-Asaba-[4]

D-Calabar-[5]

E-Okon-Eket-[5]

F- Cameroon-[20]

G- Volta (Ghana)-[59]

$\mathrm{H}$ - Average Shale Concentration [43]

I-Average Continental Crust composition [44]

ATSDR- Agency for Toxic Substances and Diseases Registry: Minimum Risk Level [45]

Recommended Daily intake [46]

Mean $^{\mathrm{a}}=$ Consumed Clay (This Study)

Mean $^{\mathrm{b}}=$ Nonconsumed Clay (This Study)

pregnant women who are habitual consumers of this clay, owning to the fact that these trace elements have no recommended guidelines of any quantity for their consumption because of their toxic nature and presented by, [47].

\subsection{Mineralogical characteristics}

The mineral compositions of the geophagic clay were determined following the obtained X-ray diffractogram patter presented in Figs. 4-11 of the supplementary materials. And the summary results of the mineral found are presented in Table 5. The result showed that kaolinite was the dominant mineral in all the selected eight (8) samples analysed. The highest amount of kaolinite was found in samples BnG5B (76.7\%) while the lowest was found in $\mathrm{BnG} 2 \mathrm{~A}$ (54.2\%). Kaolinite mineral abundance was closely followed by quartz, in all the samples. The highest amount of quartz was found in BnG7B (38.9\%) and was closely followed by BnG $1 \mathrm{~A}(33.4 \%)$, while the sample with the lowest quartz was found in BnG7A $(11.7 \%)$. Other minerals present in the analysed samples were muscovite, anatase, pyrite, calcite, gypsum, smectite and rutile which occurred in relatively lower amount. The relative abundance of kaolinite in the eight (8) samples showed that the geophagic clay in the area is essentially rich in kaolin, making the clay a kaolinite rich clay, with relatively fair amount of quartz and as well as other minor/trace amount of other minerals. Also, it was observed that smectite content in the consumed clay samples was found in BnG1A (15.2\%), BnG6A (9.7\%) and $B n G 9$ (10.4\%) which were fairly higher compare to the nonconsumed samples as observed in sample BnG1B (1.5\%) and BnG5B (1.2\%). 
Table 4 Comparison of estimated probable daily intake (PDI) with WHO/FAO standard [29]

\begin{tabular}{llll}
\hline Elements & $\begin{array}{l}\text { Mean Conc. } \\
(\mathrm{mg} / \mathrm{kg})\end{array}$ & $\begin{array}{l}\text { Estimated daily } \\
\text { intake }(\mu \mathrm{g} / \text { day })\end{array}$ & $\begin{array}{l}\text { WHO/FAO } \\
\text { PMTDI }(\mu \mathrm{g} / \\
\text { day })\end{array}$ \\
\hline $\mathrm{Cu}$ & 15.0 & 300 & 100.0 \\
$\mathrm{~Pb}$ & 14.4 & 288 & 50.0 \\
$\mathrm{Zn}$ & 30.9 & 618 & 110.0 \\
$\mathrm{Co}$ & 8.9 & 178 & $\mathrm{~N} / \mathrm{A}$ \\
$\mathrm{Mn}$ & 39.4 & 788 & 490.0 \\
$\mathrm{Th}$ & 10.5 & 210 & N/A \\
$\mathrm{Sr}$ & 13.5 & 270 & 100.0 \\
$\mathrm{~V}$ & 27.8 & 556 & N/A \\
$\mathrm{La}$ & 16.1 & 322 & 100.0 \\
$\mathrm{Cr}$ & 24.3 & 486 & N/A \\
$\mathrm{Ba}$ & 60.0 & 1200 & N/A \\
$\mathrm{Sc}$ & 7.3 & 146 & N/A \\
$\mathrm{Ni}$ & 14.6 & 292 & 5.0 \\
\hline
\end{tabular}

PMTDI: Permitted Maximum Tolerable Daily Intake

WHO: World Health Organization

FAO: Food and

Agriculture Organization

$\mathrm{N} / \mathrm{A}=$ Not Available

\section{Discussion}

The consumed clay mineral composition was also compared with geophagic clays consumed by humans in other parts of the world and geophagic clays of southern part of Nigeria. And from the results, it shows some similarities with those of China, Zimbabwe, Uganda and Indonesia (Table 6) which all have kaolinite as a dominant constituent. The samples studied show marked compositional differences from geophagic materials from other parts of the world; for example, smectite is dominant in some of the geophagic clays of China and Indonesia, while halloysite is the dominant clay mineral in geophagic materials of USA and Indonesia; illite is present in subordinate percentages in geophagic clays of USA and Indonesia, while it is found in southern Nigeria geophagic clays only in trace percentages.

The geophagic clay studied has been found to have been formed through secondary (weathering) processes hence, deposited within Benin Formation, of the Niger delta basin of Nigeria, [36]. Therefore, the process of deposition may have been made possible through activities such as groundwater flow, surface water runoff before deposition. During the period, ionic species are lost or depleted, which gives room for clay mineral purity and accumulation, [48].

The health risk associated with the consumption of clay is largely a function of the $\mathrm{pH}$ values of not just the clay itself, but also base on the $\mathrm{pH}$ values of the internal organs that directly interact with the consumed clay, [32]. Saliva, gastric juice, duodenal juice and bile have been reported by $[30,32,49]$, to range from 1 to $8 \mathrm{pH}$ values within the digestive system. It is on this bases that the bioavailability/ accessibility of these (quartz, pyrite, rutile, muscovite and smectite) minerals and harmful elements $(\mathrm{Pb}, \mathrm{Cr}, \mathrm{Th}, \mathrm{La}, \mathrm{Cu}$, $\mathrm{Ni}, \mathrm{Co}$ and $\mathrm{V}$ ) are of concern.

Mineralogically, the Uteh-Uzalla geophagic clay is essentially rich in kaolin and quartz with some traces of smectite for the consumed clay. Quartz in the clay may pose health risk to those patronizing and frequently indulging in the consumption of the clay. This is because by hardness scale, quartz is significantly hard and has been reported to be harder than dental enamel in the human system [5]. This may by implication curse damaging effect on the internal system. Again, for the fact that quartz in the clay passes through the gastrointestinal tract, can accumulate in the colon and possibly lead to rupture in the colon as earlier reported by [50].

Table 5 Mineralogical Composition of Geophagic Clays in the study area (\%)

\begin{tabular}{|c|c|c|c|c|c|c|c|c|c|c|c|c|}
\hline \multirow[b]{2}{*}{ Minerals } & \multicolumn{7}{|c|}{ Consumed Clay } & \multicolumn{5}{|c|}{ Nonconsumed Clay } \\
\hline & $B n G 1 A$ & $\mathrm{BnG} 2 \mathrm{~A}$ & $B n G 6 A$ & $B n G 7 A$ & BnG9 & Range & Mean & $B n G 1 B$ & $B n G 5 B$ & $B n G 7 B$ & Range & Mean \\
\hline Quartz & 12.7 & 34.3 & 21.2 & 11.7 & 20 & $11.7-34.3$ & 19.98 & 33.4 & 16.9 & 38.9 & $16.9-38.9$ & 29.73 \\
\hline Pyrite & 0.3 & 6.9 & 2.5 & 3.2 & 2.1 & $0.3-6.9$ & 3 & 0 & 0 & 0 & $0-0$ & 0.00 \\
\hline Kaolinite & 69.5 & 54.2 & 64.4 & 71.4 & 64.9 & $54.2-71.4$ & 64.88 & 62.3 & 76.7 & 58.9 & $58.9-76.7$ & 65.97 \\
\hline Anatase & 1.4 & 1.7 & 1.6 & 1.8 & 1.6 & $1.4-1.8$ & 1.62 & 2.2 & 2.9 & 2.1 & $2.1-2.9$ & 2.40 \\
\hline Rutile & 0.5 & 0.9 & 0.6 & 0.6 & 0.8 & $0.5-0.9$ & 0.68 & 0.2 & 0.6 & 0 & $0-0.6$ & 0.27 \\
\hline Muscovite & 0.1 & 0 & 0 & 0 & 0.2 & $0-0.1$ & 0.06 & 0 & 1.3 & 0 & $0-1.3$ & 0.43 \\
\hline Smectite & 15.2 & 1 & 9.7 & 11.4 & 10.4 & $1-15.2$ & 9.54 & 1.5 & 1.2 & 0 & $0-1.5$ & 0.90 \\
\hline Calcite & 0.4 & 0 & 0 & 0 & 0 & $0-0.4$ & 0.08 & 0.4 & 0.4 & 0 & $0-0.4$ & 0.27 \\
\hline Gypsum & 0 & 1 & 0 & 0 & 0 & $0-1$ & 0.2 & 0 & 0 & 0 & $0-0$ & 0.00 \\
\hline
\end{tabular}


Table 6 Comparison of Geophagic Clay in this study with other parts of Nigeria and the world

\begin{tabular}{|c|c|c|c|c|c|c|c|c|c|}
\hline & Asaba & Ekiti & Ibadan & This study & & & & & \\
\hline (Study Area) & & & & & 1 & 2 & 3 & 4 & 5 \\
\hline Kaolinite & Dorm & Abunt & Abunt & Dorm & Abunt & & Abunt & Dorm & Sub \\
\hline Smectite & & & & $\mathrm{Tr}$ & Dorm & Sub & & Sub & Dorm \\
\hline Halloysite & & $\operatorname{Tr}$ & & & Sub & Dorm & Sub & & Dorm \\
\hline Nontronite & Abunt & & & & & & & & \\
\hline Palygorskite & Abunt & Sub & Sub & & & & & & \\
\hline Illite & $\operatorname{Tr}$ & & $\operatorname{Tr}$ & & & Sub & & & \\
\hline K- Feldspar & $\mathrm{Tr}$ & & $\mathrm{Tr}$ & & & & & & Sub \\
\hline
\end{tabular}

Dorm-Dominant (>50\%), Abunt-Abundant (25-50\%), Sub-Subordinate (5-25\%), Tr-Trace $(<5 \%)$

1-China [58]

2-U SA [61]

3-Zimbabwe [61]

4- Uganda [62]

5- Indonesia [63]
According to [51], kaolin rich clay is chemically inert in nature over a wide range of $\mathrm{pH}$ values; the mineral assists as antiacid, and hence inhibits corrosive activities. [48] reported that Cation Exchange Capacity (CEC) of kaolinitic clay is found to be among the lowest of clay minerals, thereby allowing for little exchangeable ions exchanges sites. Beside these, the particle size of clay assists in the formation of coating in and around the gastro-intestinal walls. These properties measured above, is summarily reported to that kaolin serves as protective minerals for intestinal organs [52] which is the reason pharmaceuticals make good use of clay for medicinal active ingredient carriers for gastrointestinal disorder treatments, [5]. The highlighted relevance of kaolin in clay may have been the reasons for the consumption of this clay in many parts of the country. Nevertheless, the mere fact that this clay is consumed may put the consumers at risk healthwise.

Similarly, the presence of some potentially harmful elements in the geophagic clay is of concern. These elements include $\mathrm{Pb}, \mathrm{Cu}, \mathrm{Th}, \mathrm{V}, \mathrm{Co}, \mathrm{La}, \mathrm{Sc} \mathrm{Ni}, \mathrm{V}, \mathrm{Cr}$ and $\mathrm{Sr}$. The American Agency for Toxic Substances and Diseases Registry (ATSDR) [45] has reported that oral consumption of $\mathrm{Pb}$, Th, La and $\mathrm{Sc}$ is not allowed, no matter how little in quantity that is present. These elements can be extremely toxic to the human internal system. The health toxic effects of $\mathrm{Pb}$ oral consumption include hearing loss, reduction in intellectual quotient, for children, [53]. However, for adults, it can cause kidney and fertility systems damage and anaemia, [20,54,55]. Cr oral consumption may cause lung cancer and dermatitis just as $\mathrm{Ni}$ oral consumption also has ability to cause respiratory diseases, $[56,57]$. Th and La have radioactive isotope that causes toxic effect to the lungs, liver, brain and other vital organs of the body, which can degenerate to cancer of those organs, $[55,58]$. High oral consumption of Co can lead to asthma and pneumonia, even though low consumption has positive benefits such as stimulation of the red blood cells in the body. Other trace elements determined $\mathrm{Zn}$ and $\mathrm{Ba}$ have some relatively positive health benefits when consumed. $\mathrm{Zn}$ for example is considered nontoxic, when consumed within tolerable dose. However, when the consumption of $\mathrm{Zn}$ exceeds acceptable limit, it can lead to electrolyte imbalance, renal failure, abdominal pain, vomiting, impair immune responses, among other health risk, $[52,55]$.

Since most of these harmful and toxic trace elements are significantly present in the studied clay, in some case more than 200- to 300-fold higher than the recommended threshold for oral consumption by the American Agency for Toxic Substances and Diseases Registry (ATSDR), it can be said that the studied clay may be unsafe for consumption. This is further buttressed by the result of the estimated probable daily intake whose result showed significant effect when compared with the WHO/FAO standards of metal intake per day.

However, it can be said that we cannot satisfactorily estimate the health risk that are scientifically associated with the consumption of geophagic clay. Most of the exposure factors and individual risk factors as expressed by $[30-32,59,60]$ are poorly known based on the scope of this research; hence, more scientific information is needed with respect to nature and provenance of the geophagic clay, bioavailability and bioaccessibility of these potentially harmful elements (PHEs) as well as harmful minerals in the clay samples, consumption habits of the pregnant women that are known to consuming this clay, breastfeeding mothers and children. Similarly, the frequency level will further add to knowing the health risk of these PHEs and minerals of this clay as reported by $[30-32,60]$. 


\section{Conclusion}

The geophagic clay samples collected from Uteh-Uzalla mine site were assessed; the clay is derived from secondary sedimentary environment. The $\mathrm{pH}$ of the clay samples showed slightly to moderately acidic with a $\mathrm{pH}$ value of between 3.19 and 6.01. The result of $x$-ray diffraction shows abundance of kaolinite in all the clay samples analysed. The dominance of kaolinite and to a lesser extent smectite may have been the reason for the continuous consumption of this clay because of the antiacid effect that it has on the digestive system. Quartz was also found in all the samples as the second most abundant element. Other minerals that occurred in minor percentage include anatase, pyrite, rutile, muscovite, calcite and gypsum, which by their concentration may not have significant health risk to the human internal system. The relatively high percentage of quartz is of concern because the mineral is hard in physical form and may cause colon rupturing, which is a very serious health risk that calls for concern.

Trace elements contents ( $\mathrm{Cu}, \mathrm{Pb}, \mathrm{Zn}, \mathrm{Co}, \mathrm{Mn}, \mathrm{Th}, \mathrm{Sr}, \mathrm{V}$, La, $\mathrm{Cr}, \mathrm{Ba}, \mathrm{Sc}$ and $\mathrm{Ni}$ ) that were analysed showed relatively elevated concentration in all the samples. The trace elements results when compared with American Agency for Toxic Substances and Diseases Registry and recommended daily intake by [Belitz, 2009], it was found that the elements are far above the daily oral intake (Threshold) requirement. The presence of $\mathrm{Pb}, \mathrm{La}$, Th and Sc elements in the studied clay possibly poses serious health risk. These elements are referred to as high priority toxic elements that need not be present in what human beings consume especially in it natural form. Since the concentration of essential elements such as $\mathrm{Zn}, \mathrm{Mn}, \mathrm{Ba}$, among others, is far more than the tolerable limit of intake in the study samples, their continuous consumption of this clay need be discouraged because of the possible health implications. Apparently no doubt, geophagic clay consumption is known to be age-long practices among women and children in both rural and semi urban dwellers, discouraging people who are used to it will be difficult because of some inherent health benefits and habits. Because of the scope of this research, it should be said that studies on the bioaccessibility and bioavailability of this clay will in no small means give more information on the health risk, if any, of the consumption of this clay.

Acknowledgements I am very grateful to Ogunleye J.B, Akinyele H.O and Adebola J.A, for their immeasurable contributions towards the success of this research.

\section{Declarations}

Conflict of interest I hereby state that I am the author of this article; there is no conflict of interest in this article.
Open Access This article is licensed under a Creative Commons Attribution 4.0 International License, which permits use, sharing, adaptation, distribution and reproduction in any medium or format, as long as you give appropriate credit to the original author(s) and the source, provide a link to the Creative Commons licence, and indicate if changes were made. The images or other third party material in this article are included in the article's Creative Commons licence, unless indicated otherwise in a credit line to the material. If material is not included in the article's Creative Commons licence and your intended use is not permitted by statutory regulation or exceeds the permitted use, you will need to obtain permission directly from the copyright holder. To view a copy of this licence, visit http://creativecommons. org/licenses/by/4.0/.

\section{References}

1. Gomes CSF (2016) Healing and edible clays: a review of basic concepts, benefits and risks. Environ Geochem Healthm. https:// doi.org/10.1007/s10653-016-9903-4

2. Okunlola OA, Owoyemi KA (2011) Compositional characteristics of Geophagic clays of southern Nigeria. In: Ekosse G-I E, de Jager L, Ngole VM (Ed). An innovative Perspective on the role of Clays and clay minerals in Africa. Book of Conference Proceedings. Central University of Technology, Bloemfontein, South Africa

3. Gomes CSF, Silva JBP, Gomes JHC (2015) Natural peloids versus designed and engineered peloids. Boletı'n/Sociedad Españ ola de Hidrología Me'dica 30(1):15-36

4. Okunlola OA, Amusa OM, Omitogun AA (2016) Geophagic Clays of Nigera: Compositional Feastures and Health Implications. J Min Geol 52(2):129-151

5. Olatunji AS, Olajide-Kayode JO, Abimbola AF (2014) Evaluation of geochemical characteristics and health effects of some geophagic clays southern Nigeria. Environ Geochem Health 36:3

6. Halsted JA (1968) Geophagia in man: its nature, and nutritional effects. Am J Clin Nutr 21:1384-1393

7. Laufer B (1930) Geophagy. Field Museum Natl Hist Anthropol Ser 18:99-198

8. Meijide R, Burguera EF, Vela-Anero A (2015) Peloterapiay Artrosis Balnea 10:289-300

9. Ekosse GE, Ngole VM (2012) Mineralogy, geochemistry and provenance of geophagic soils from Swaziland. Appl Clay Sci 57:25-31

10. Kreulen DA (1985) Lick use by large herbivores: A reviewof benefits and banes of soil consumption. Mammal Rev 15:107-123. https://doi.org/10.1111/j.13652907.1985.tb00391.x

11. Kortei NK, Koryo-Dabrah K, Akonor PT, Manaphraim NY, AyimAkonor M, Boadi NO, Essuman EK, Tettey C (2020) Potential health risk assessment of toxic metals contamination in clay eaten as pica (geophagia) among pregnant women of $\mathrm{Ho}$ in the Volta Region of Ghana. BMC Pregnancy and Childbirth (2020), vol 20, p 160. https://doi.org/https://doi.org/10.1186/ s12884-020-02857-4

12. Reilly C, Henry J (2000) Geophagia: why do humans consume soil? Nutr Bull 25(2):141-144

13. Woywodt A, Kiss A (2002) Geophagia: the history of earth-eating. J Royal Soc Med 95:143-146

14. Mattioli M, Giardini L, Roselli C, Desideri D (2016) Mineralogical characterization of commercial clays used in cosmetics and possible risk for health. Appl Clay Sci 119:449-454

15. Meijide R, Mourelle ML, Vela-Anero A, Lo'pez EM, Burguera EF, Pe'rez CG (2014) Aplicacio'n a pacientes: Peloterapia en patologias dermatolo'gicas. In: AH Torres (Ed.), Peloterapia: Aplicaciones médicas y cosme'ticas de fangos termales. Fundacio'n para la Investigacio 'n y Innovacio'n en Hidrologia 
Me'dica y Balneoterapia "BI'lbilis" (pp 169-183). Madrid. ISBN: 978-84-616-8551-6

16. Momoh A (2013) Mineralogical, geochemical and health impacts of earth materials consumed by humans in Vhembe district of Limpopo Province, South Africa. PhD thesis abstract, unpublished Library item: 20130665, University of Venda, South Africa

17. Brand CE, De-Jager L, Ekosse GE (2010) Possible health effects associated with human geophagic practice: an overview. South African Medical Technology 23:11-13

18. Ekosse EG, Jumbam ND (2010) Geophagic clays: their mineralogy, chemistry and possible human health effects. Afr J Biotechnol 9(40):6755-6767

19. Gomes CSF (2013) Naturotherapies based on minerals. Geomaterials 3:1-14

20. Ekosse GE, De Jager L, Ngole VM (2010) Traditional mining and mineralogy of Geophagic clays from Limpopo and Free State Provinces, South Africa. Afr J Biotech 9:8058-8067

21. Ferrell RE (2008) Medicinal clay and spiritual healing. Clays Clay Miner 56:751-760

22. Lar UA, Agene Jl, Umar Al (2014) Geophagic clay materials from Nigeria: a potential source of heavy metals and human health implications in mostly women and children who practice it. Environ Geochem Health. https://doi.org/10.1007/ s10653-014-9653-0

23. Maraver F, Fernandez-Tora'n MA, Corvillo I, Morer C, Va'quez I, Aguillera L (2015) Peloterapia: Una Revisio'n. Med Nat 9(1):38-46

24. Trivedi TH, Daga GL, Yoelekar ME (2005) Geophagia leading to hypokalemic Quadriparesis in a postpartum Patient. JAP 153:205-207

25. Ljung K, Selinus O, Otabbbong E, Berglund M (2006) Metal and Arsenic distribution in soil particle sizes relevant to soil ingestion in children. Appl Geochem 21:1613-1624

26. Bonglaisin JN, Mbofung CMF, Lantum DN (2011) Intake of lead, cadmium and mercury in kaolin-eating: A quality control. J Med Sci 11(7):267-273

27. Owumi SE, Oyelere AK (2015) Determination of metal ion contents of two antiemetic clays used in geophagy. Toxicol Rep 2:928-932

28. Photos-Jones $E$, Keane $C$, Jones $A X$, Stamatakis $M$, Robertson $P$, Hall AJ (2015) Testing dioscorides' medicinal clays for their antibacterial properties: the case of Samian Earth. J Archaeol Sci 57:257-267

29. Sa'nchez-Espejo R, Aguzzi C, Cerezo P, Salcedo I, Lo'pez-Galindo A, Viseras C (2014) Folk pharmaceutical formulations in western Mediterranean: Identification and safety of clays used in pelotherapy. J Ethnopharmacol 155:810-814

30. Gretchen LS, Elad T, Cedric A, Raymond PG, Sera LY (2016) A novel in vivo model for assessing the impact of geophagic earth on iron status nutrients, vol 8, p 362. doi:https://doi.org/ $10.3390 /$ nu8060362

31. Seim G, Ahn C, Bodis M, Luwedde F, Miller D (2013) Bioavailability of iron in geophagic earths and clay minerals, and their effect on dietary iron absorption using an in vitro digestion/ Caco-2 cell model. Food Funct 4:1263-1270

32. Kutalek R, Wewalka G, Auer H, Wilson J, Haluza D, Huhulescu S, Hillier S, Sager M, Armin P (2010) Geophagy and potential health implications: geohelminths, microbes and heavy metals. Trans R Soc Trop Med Hyg 104:787-795

33. Hooda P, Henry C, Seyoum T (2004) The potential impact of soil ingestion on human mineral nutrition. Sci Total Environ, vol 333, pp 75-87. in clay balls: problem of geophagia practice in Ghana. Environ Geochem Health DOI
34. Pebsworth P, And SG, Huffman M (2013) Soil consumed by Chacma baboons is low in bioavailable iron and high in clay. $J$ Chem Ecol 39:447-449

35. WHO. Food Additive and contaminants (Flavours; Cadmium and lead), 2011. Geneva: Seventy-third Meeting of the Joint FAO/ WHO Expert Committee on Food Additives (JECFA). p 1-535

36. Nwajide CS (2013) Geology of Nigeria's sedimentary basins. CSS Bookshop Ltd., Lagos, Nigeria, p 565

37. Kogbe CA (1975) Geology of Nigeria. University of Ife Press

38. Short KC, Stauble AJ (1967) Outline of the geology of Niger delta. Am Assoc Petrol Geol 51:761-779

39. Akujieze CN (2004) Effects of Anthropogenic activities on urban groundwater system and aquifer vulnerability assessment in Benin City, Edo state, Nigeria. Ph.D. Thesis University of Benin; 2004

40. Akujieze CN, Oteze GE (2007) Deteriorating quality of groundwater in Benin City, Edo state Nigeria. Water Resour J Nigerian Associat Hydrogeol 1(2):19-196

41. Abrahams PW, Davies TC, Solomon AO, Trow AJ, Wragg J (2013) Human geophagia, calabash chalk and undongo: mineral element nutritional implications. PLoS ONE 8(1):e53304. https:// doi.org/10.1371/journal.pone.0053304

42. Miller JD, Collins SM, Omotayo M, Martin SL, Dickin KL, Young SL (2018) Geophagic earths consumed by women in western Kenya contain dangerous levels of lead, arsenic, and iron. Am J Hum Biol. https://doi.org/10.1002/ajhb.23130

43. Turekian KK, Wedepohl LH (1961) Distribution of elements in some major units of the Earth crust. Am Geol Soc Bull 72:125

44. Taylor SR, McLennan SM (1985) The continental crust: its composition and evolution. Blackwell, Oxford

45. Agency for Toxic Substances and Disease Registry (ATSDR) 2019. Minimal Risk Level. www.atsdr.cdc.gov/MRLs.

46. Belitz HD, Grosch W, Schieberle P (2009) Food chemistry. p 425

47. Schmidt RH, Rodrick GE (2005) Food safety handbook. Wiley, Hoboken. https://doi.org/10.1002/047172159X

48. Ekosse G (2001) Provenance of the Kgwakgwe kaolin deposit in south eastern Botswana and its possible utilization. J Appl Clay Sci 20(3):137-152

49. Oomen AG, Sips AJAM, Groten JP, Dick TJM, Sijm THM, Tolls J (2000) Mobilization of PCBs and lindane from soil during in vitro digestion and their distribution among bile salt micelles and proteins of human digestive fluid and the soil. Environ Sci Technol 34:297-303

50. Jahanshahee A, Pipelzadeh MH, Ahmadinejad M (2004) A case report of colon and rectum obstruction because of sand in a three-year-old boy. Arch Iran Med 7(1):66-67

51. Murray HH (1963) Mining and processing industrial kaolins. Georgia Mineral Newsletter 16:3-11

52. Young SL, Wilson ML, Miller D, Hillier S (2008) Towards a comprehensive approach to the collection and analysis of pica substances with emphasis on geophagic materials. PLoS ONE 3(9):e3147

53. Merian E, Anke M, Ihnat M, Stoeppler M (2004) Elements and their compounds in the environment-vol 2. Metals and their compounds, Wiley-VCH, Germany, pp 20-48

54. Okorie IA (2010) Determination of potentially toxic elements (PTEs) and an assessment of environmental health $r$ isk from environmental mat $r$ ices. Doctoral thesis, Northumbria University, p 201

55. Poggio L, Vrscaj B, Rainer S, Erwin H, Ajmone F (2009) Metals pollution andhuman bioaccessibility of topsoils in Grugliasco (Italy). Environ Pollut, pp 157680-689

56. Alloway BJ (1995) The origin of heavy metals in soils. In: Alloway BJ (ed) Heavy metals in soils. Blackie Academic and Professional, London, UK, pp 38-57 
57. World Health Organisation (1978) The promotion and development of traditional medicine: report of a WHO meeting. Geneva, WHO. WHO Tech. Rep. Ser., vol 622, p 44

58. Alloway BJ (1991) Heavy metals in soils. UK: Blackie Academic and Professional; 1995

59. Arhin E, Zango MS (2015) Determination of trace elements and their concentrations in clay balls: problem of geophagia practice in Ghana. Environ Geochem Health. https://doi.org/10.1007/ s10653-016-9801-9

60. Momoh A, Ojo OJ, Odewumi SC, Sibiya BK (2013) Preliminary results of selected toxic trace elements in geophagic clays from the vhembe district. South Africa 119:449-454

61. Wilson MJ (2003) Clay mineralogical and related characteristics of geophagic materials. J Chem Ecol 29(7):1525-1547

62. Abrahams PW, Parsons JA (1997) Geophagy in the tropics An appraisal of three geophagical materials. Environ Geochem Health 19:19-22

63. Mahaney WC, Milner MW, Mulyono H, Hancock RGV, Aufreiter S, Reich M, Wink M (2000) Mineral and chemical analyses of soils eaten by humans in Indonesia. Int J Environ Health Res 10:93-109

64. Aufreiter S, Hancock RGV, Mahaney WC, Stambolic RA, Sanmugadas K (1997) Geochemistry and mineralogy of soils eaten by humans. Int J Food Sci Nutr 48(5):293-305

65. Calabrese EJ, Stanek EJ, Gilbert C (1991) Evidence of soil-pica behavior and quantification of soil ingested in children who practice it. Environ Geochem Health. https://doi.org/10.1007/ s10653-014-9653-0

66. World Health Organisation (1993) Guidelines for drinking water quality, 2nd edn. World Health Organisation, Geneva

Publisher's Note Springer Nature remains neutral with regard to jurisdictional claims in published maps and institutional affiliations. 